\title{
C-Repeat Binding Factor and Dehydrin Genes are Induced Co-Ordinately in Drought Tolerance Response of Wheat Cultivars
}

\author{
Csilla Deák ${ }^{1}$, Katalin Jäger ${ }^{2}$, Veronika Anna Nagy ${ }^{1}$, Réka Oszlányi ${ }^{1}$, Beáta Barnabás ${ }^{2}$ \& István Papp ${ }^{1}$ \\ ${ }^{1}$ Department of Plant Physiology and Plant Biochemistry, Faculty of Horticultural Science, Szent István \\ University, Budapest, Hungary \\ ${ }^{2}$ Agricultural Institute, Centre for Agricultural Research, Hungarian Academy of Sciences, Martonvásár, \\ Hungary \\ Correspondence: István Papp, Department of Plant Physiology and Plant Biochemistry, Faculty of Horticultural \\ Science, Szent István University, H-1118 Budapest, Villányi út 29-43, Hungary. Tel: 36-1-305-7228. E-mail: \\ papp.istvan@kertk.szie.hu
}

Received: September 7, 2016

Accepted: November 18, 2016

Online Published: January 15, 2017

doi:10.5539/jas.v9n2p18

URL: http://dx.doi.org/10.5539/jas.v9n2p18

\begin{abstract}
Four bread wheat genotypes with contrasting drought stress tolerance were studied. Expression levels of dehydrin (Wdhn13) and C-repeat binding factor $(\mathrm{Cbf14}, \mathrm{Cbf15})$ genes were investigated in leaves of two drought tolerant (Plainsman V, Mv Emese) and two sensitive (GK Élet, Cappelle Desprez) cultivars by semi-quantitative RT-PCR during drought treatment at anthesis. Coordinate induction of Cbf14, Cbf15 and Wdhn 13 genes occurred at a late stage of stress treatment in all cultivars except the most sensitive Cappelle Desprez, where no induction was evident. The most pronounced late induction of genes was observed in the tolerant Mv Emese genotype. Cbf14, Cbf15 and Wdhn13 showed largely parallel changes of expression in stressed adult plants. The mRNA level of the same set of genes was measured in leaves of non-stressed seedlings with qRT-PCR method. Expression level of $W d h n 13$ was high and low in seedlings of tolerant and sensitive cultivars, respectively. $C b f 15$ specific transcript was barely detectable in leaves of non-stressed seedlings. In order to shed light on any potential difference in hormone responsiveness, seedlings were subjected to ABA treatment in vitro. At low hormone concentrations (10 and $20 \mu \mathrm{M} \mathrm{ABA}$ ) consistently weaker ABA induced root growth retardation of GK Élet was found in comparison with the other three cultivars. Results highlight pronounced and late induction of a set of defence genes and low ABA sensitivity as features appearing in drought tolerant and sensitive responses, respectively. Data is discussed in the light of multifactorial determination of the complex phenotype of drought tolerance in wheat.
\end{abstract}

Keywords: wheat (Triticum aestivum L.), drought stress, abscisic acid, dehydrin genes, CBF genes

\section{Introduction}

C-repeat binding factor $(C b f)$ genes are AP2/ERF transcription factors implicated both in cold stress response (Galiba et al., 2009) and in ABA mediated drought stress tolerance (Mizoi et al., 2012; Knight et al., 2004; Xiao et al., 2006; Kidokoro et al., 2015). Cbfl4 and Cbfl5 genes of wheat were first identified in Triticum monococcum L. and mapped to a major locus determining frost tolerance in this species (Miller et al., 2006). Cbf14 and Cbf15 of Triticum aestivum were functionally tested by transformation of barley, proving the role of these genes in freezing tolerance (Soltész et al., 2013). Along with alleviation of consequences of freezing stress, transcriptional activation of some dehydrin genes was also noted in the transgenic barley lines. Dehydrins are protective proteins against cellular damage in freezing and osmotic stress with multiple ways of functioning (Battaglia et al., 2008; Hara, 2010), complementing other molecular defences (Hegedüs et al., 2004) activated by these stress factors. Fifty-four wheat genes have been selected as candidates for coding dehydrins, most of them induced by dehydration (Wang et al., 2014). Wdhn13 is a relatively well characterized member of this group. Its ABA inducibility has been suggested by some authors (Kurahashi et al., 2009), but has not been proposed by others (Ohno et al., 2003). This gene was found to exhibit variable expression/inducibiliy in divergent cultivars in response to dehydration (Rampino et al., 2006).

Connection between abscisic acid (ABA) signalling and drought tolerance has been well established (e.g. Lee \& Luan, 2012; Golldack et al., 2014). ABA sensitivity may be manifested at any of the divergent processes this 
hormone regulates, such as germination, growth retardation or other stress responses leading to tolerance. Although these responses probably do not use the same set of signalling components, ABA sensitivity at germination for instance was found to be associated with enhanced drought tolerance in a number of cases (Cutler et al., 1996; Hugouvieux et al., 2001; Papp et al., 2004). Measuring retardation of root elongation at the seedling stage is a relatively simple way to characterize responsiveness to exogenously applied ABA (Thole et al., 2014). This trait was found to be associated with high drought stress tolerance levels in a set of synthetic hexaploid wheat lines derived from Aegilops tauschii (Kurahashi et al., 2009).

In this study, expression levels of genes potentially associated with a drought stress response were investigated in four bread wheat genotypes of contrasting drought tolerance. The cultivars were already characterized earlier and were shown to exhibit tolerance (Plainsman V, Mv Emese) or sensitivity (GK Élet, Cappelle Desprez) against drought stress (Guóth et al., 2009; Jäger et al., 2014). We hypothesized that known regulators of water stress tolerance and/or effector genes might contribute to this contrasting behaviour. As candidates, a dehydrin gene and $C B F$ transcription factors were characterized under drought conditions at anthesis. The transcription pattern of these genes was also established in non-stressed seedlings of the same cultivars. Further on we set out to compare $\mathrm{ABA}$ sensitivity of root elongation at the seedling stage to explore ABA responsiveness of the cultivars.

\section{Materials and methods}

\subsection{Growth of Plant Material, Sampling and Drought Stress Treatment}

Seeds of four winter wheat (Triticum aestivum L.) cultivars (Plainsman V, Mv Emese, GK Élet, Cappelle Desprez) were imbibed in distilled water for 1 hour at $22{ }^{\circ} \mathrm{C}$. All subsequent steps of the procedure were performed at this temperature. Imbibition was followed by surface sterilization in sodium hypochlorite with $2 \%$ available chlorine for $8 \mathrm{~min}$ and by rinsing 4 times with sterile distilled water. Imbibed seeds were germinated in glass Petri dishes on a filter paper moistened with distilled water in the darkness. The seedlings were subjected to ABA treatment immediately after the emergence of the radicle.

For water stress treatment plants of the winter wheat varieties were planted in a soil-sand-peat mixture $(3: 1: 1$, $\mathrm{v} / \mathrm{v} / \mathrm{v}$ ) after 7 weeks of vernalisation at a temperature of $4{ }^{\circ} \mathrm{C}$, and grown in PGV-15 growth chambers (Conviron, Winnipeg, Canada) using the spring climatic program T1 (Tischner et al., 1997). The $\mathrm{min} / \mathrm{max}$ temperature rose from $12.5 / 5.5{ }^{\circ} \mathrm{C}$ to $21 / 14{ }^{\circ} \mathrm{C}$ until anthesis. Irrigation was carried out regularly in the morning at a rate of 150 $\mathrm{ml} / \mathrm{pot} / \mathrm{day}$. In order to compensate for the delay in heading and flowering of Cappelle Desprez compared to the other three cultivars (according to preliminary experiments), plants of the former variety were planted 2 weeks earlier to align developmental differences. Drought stress was generated by total water withholding starting at the time of inflorescence emergence (Zadoks' growth stage 53) to complete anthesis (Zadoks' growth stage 67) until the volumetric water content of the soil dropped below $10 \%$ in the pots. Leaf samples were collected from both drought-stressed and control plants. Soil volumetric water content (VWC) of 20 pots per genotype and treatment was measured using an HH2 moisture meter (Delta-T Devices Ltd., Cambridge, UK) at field capacity and during treatments. Relative water content (RWC) of leaves was determined on whole flag leaves of three plants per genotype and treatment at the end of water withholding by measuring fresh weight (FW) at excision, saturated weight (SW) after $24 \mathrm{~h}$ rehydration on distilled water at $4{ }^{\circ} \mathrm{C}$ in the dark, and dry weight (DW) after oven drying for $48 \mathrm{~h}$ at $80^{\circ} \mathrm{C}$. The leaf RWC (\%) was calculated using the following equation:

$$
\mathrm{RWC}(\%)=[(\mathrm{FW}-\mathrm{DW}) /(\mathrm{SW}-\mathrm{DW})] \times 100
$$

For sample preparation of non-stressed young seedlings, plants were planted as above and were grown at constant $21{ }^{\circ} \mathrm{C}$ temperature under 10/14 hours light/dark illumination cycle. At Zadok's growth stage 13 leaves of seedlings were harvested for RNA preparation (Zadoks et al., 1974).

\subsection{RNA Extraction, RT-PCR, qRT-PCR, DNA Fragment Isolation and Sequencing}

Leaf samples were grinded in liquid nitrogen and RNA was isolated with Tri Reagent (Molecular Research Center, Cincinnati, OH, USA) according to the instructions of the manufacturer. First strand cDNA synthesis kit (Fermentas, Vilnius, Lithuania) was used for reverse transcription of the RNA samples. RT-PCR was performed with GoTaq Flexi DNA Polymerase from Promega (Madison, WI, USA) according to the instructions of the manufacturer, applying a total of 30 cycles. An equal use of cDNA templates was confirmed by RT-PCR with control primers TalKa and TalKb, amplifying sequence Ta2776, as suggested by Paolacci et al. (2009). The gene-specific primers for the dehydrin gene were designed with the Primer Premier software (Premier Biosoft, Palo Alto, CA, USA) and were purchased from Biomi Kft (Gödöllö, Hungary) or Sigma (St Luis, MI, USA). Primers specific for the CBF genes were kindly provided by Gábor Galiba (Agricultural Institute of HAS, Martonvásár, Hungary). All primers used are listed in Table 1. qRT-PCR was performed in a Rotor Gene 6000 
instrument (Corbett Research, Australia), by applying conditions recommended by the manufacturer and $60{ }^{\circ} \mathrm{C}$ annealing temperature. Quality of products was confirmed with melting curve analysis by heating samples from $66{ }^{\circ} \mathrm{C}$ to $99{ }^{\circ} \mathrm{C}$ in $0.5^{\circ} \mathrm{C}$ increments. Evaluation of data was done with the help of Comparative Quantitation Analysis program (McCurdy et al., 2008). RT-PCR and qRT-PCR were performed at least two times on different biological samples with a minimum of two technical repetitions in each case. RT-PCR products were purified from agarose gels using an Illustra GFX PCR DNA and gel band purification kit (GE Healthcare, Uppsala, Sweden). Primary DNA sequences were determined by Biomi Kft (Gödöllö, Hungary). Differences of genes expression levels were tested with one-way ANOVA.

\subsection{Measuring Root Growth Retardation of Seedlings in Response to ABA Treatment}

Synchronously germinated seedlings were transferred into Petri dishes with filter paper wetted with distilled water or with 10,20 or $50 \mu \mathrm{M}$ ABA (Sigma) solution. At least 40 seedlings per treatment and genotype were incubated for further one week in the darkness and the lengths of their primary roots were recorded. The experiment was repeated three times. Differences in root length were tested with one-way ANOVA and a subsequent Dunnett's T3 (T3) test (Dunnett, 1955).

\section{Results}

\subsection{Drought Stress Treatment}

As a consequence of water deprivation soil volumetric water content declined below $10 \%$ in all cultivars by the end of the treatment (Figure 1). There was no consistent, significant difference in the dynamics of water loss among the cultivars based on repetitions of the experiment. Relative water content of leaves remained significantly higher in the drought tolerant cultivars (Figure 2).

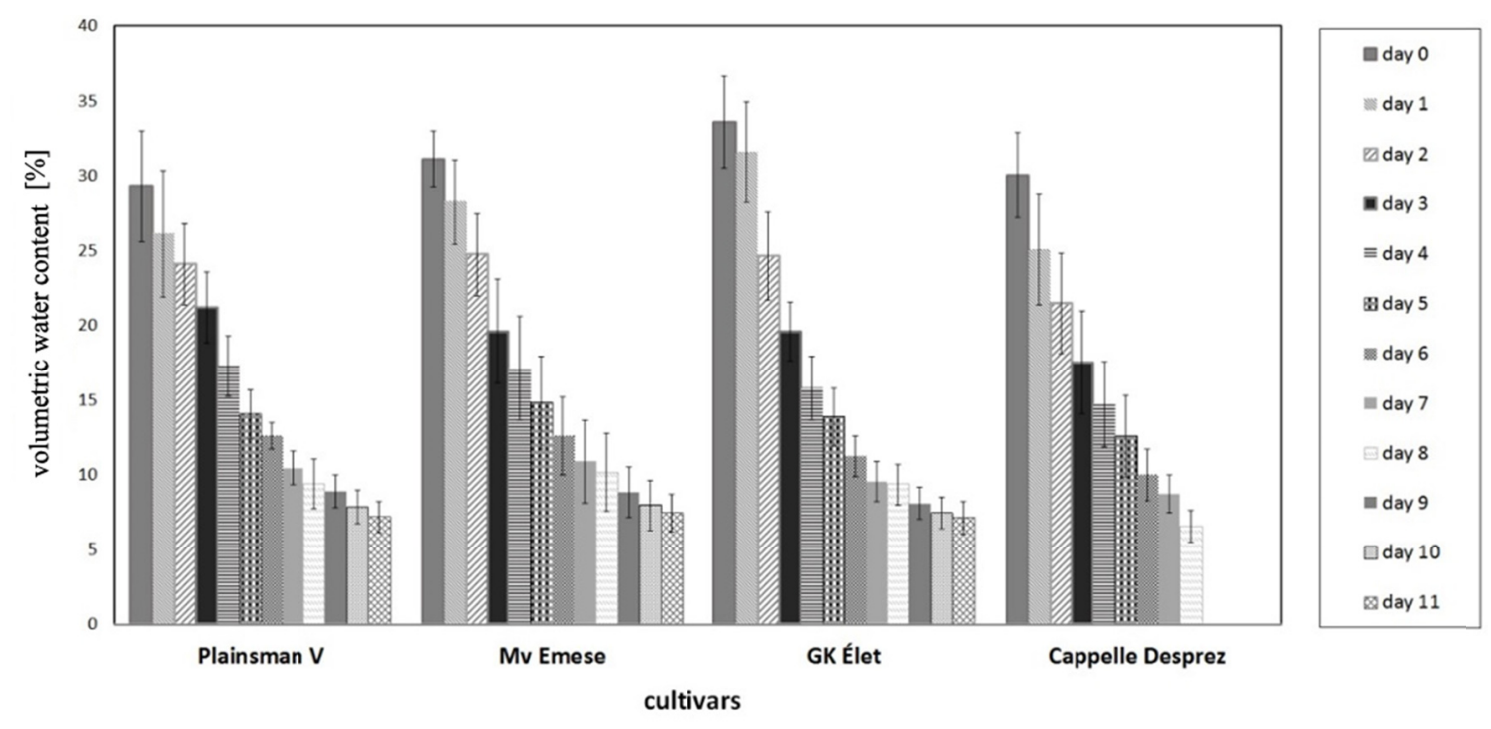

Figure 1. Volumetric water content (VWC) of soil during drought stress. Number of days of the treatment is indicated. Means \pm standard deviations are shown 


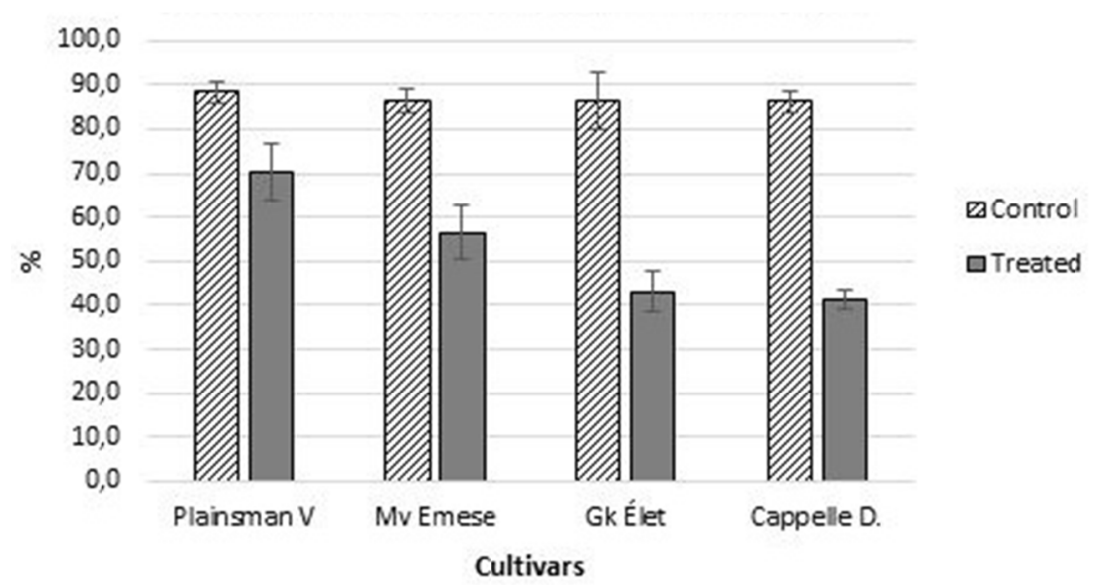

Figure 2. Relative water content (RWC) of leaves at the end of the treatment. Means \pm standard deviations are shown

\subsection{Transcriptome Analysis in Adult Plants under Water Deprivation}

Gene specific RT-PCR product from Wdhn13 was most induced in Mv Emese at $6^{\text {th }}-10^{\text {th }}$ days of water deprivation (Figure 3). mRNA of this gene was barely detectable in the other three genotypes, with low level of induction in Plainsman V and Gk Élet. Declining signal in semi quantitative RT-PCRs of all studied genes was followed by a wave of induction around the $8^{\text {th }}$ day of treatment, except for the most sensitive Cappelle Desprez, where this induction did not occur. Parallel changes in expression of Cbf14, Cbf15 and Wdhn13 genes were noted, but this effect was not stringent. In order to confirm identity of the PCR products representative RT-PCR fragments of $C b f 14, C b f 15$ and $W d h n 13$ were extracted from agarose gels and sequenced directly.

Table 1. Gene specific and control primers used in RT-PCRs and qRT-PCR

\begin{tabular}{ll}
\hline Primer name & Primer sequence \\
\hline Cbf14a & 5'-CCAAACCAGTGTCATTCAA-3' \\
Cbf14b & 5'-TTGTCTCAACTTCGCCACT-3' \\
Cbf15a & 5'-GTGTCTCAACTTCGCCGACT-3' \\
Cbf15b & 5'-ATGTGTCCAGGTCCATTTTCC-3' \\
Wdhn13a & 5'-ATTCTGCAAAGTAGCGGGTC-3' \\
Wdhn13b & 5'-AGAACCAGTGTCAGATTTCCCT-3' \\
TalKa & 5'-GTAGCATTATGTTTGTGCCTTG-3' \\
TalKb & 5'-GGAGAGCCAGTCAAGACCCTCG-3' \\
\hline
\end{tabular}

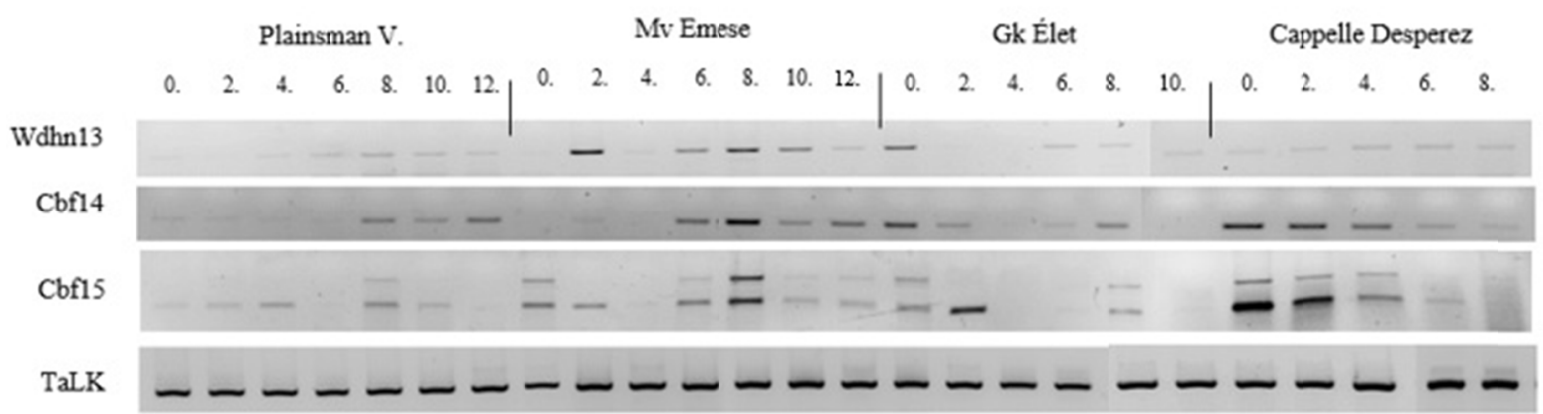

Figure 3. RT-PCR products for the studied genes in the four genotypes during drought stress treatment. Numbers indicate days of treatment 


\subsection{Transcript Abundance of Cbf14, Cbf15 and Wdhn13 Genes in Non-Stressed Seedlings}

Quantitative RT-PCR was performed on cDNA samples prepared from unstressed seedlings of the cultivars studied. Transcript abundance of the genes was investigated in leaves of 3 week old non-stressed plants. Data show high expression of Wdhn13 occurring exclusively in the tolerant cultivars (Plainsman V and Emese) (Figure 4). mRNA levels of the CBF14 gene were generally modest, highest in the cultivar Plainsman V. mRNA of the $C b f 15$ gene however was not detected at all under these conditions, or its level was extremely low.

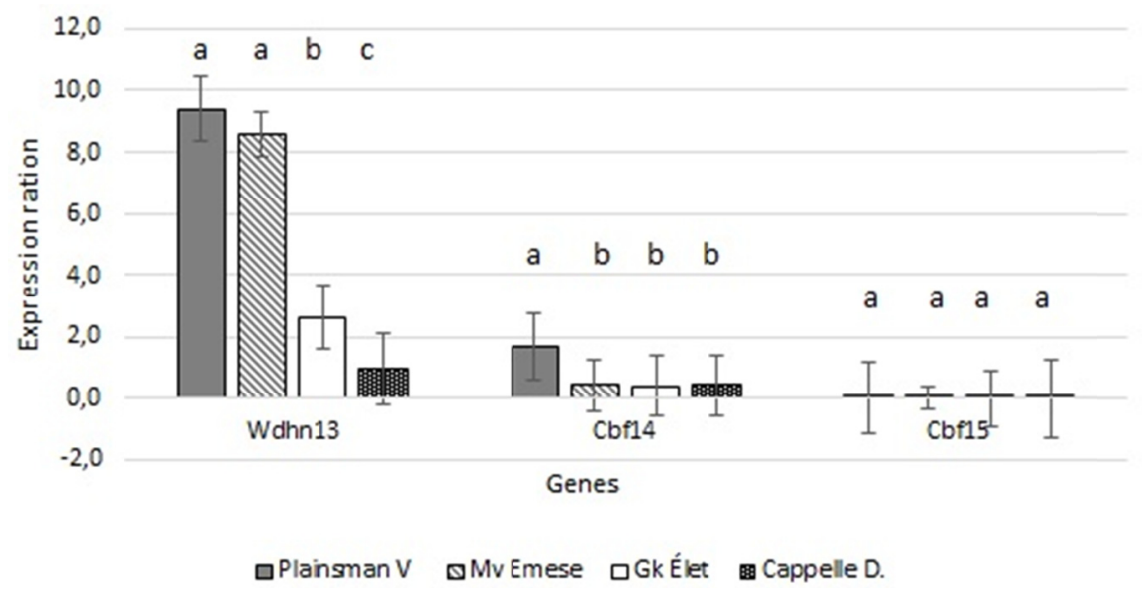

Figure 4. Expression levels of the genes, measured by qRT-PCR, in unstressed seedlings. One-way ANOVA with post-hoc Tukey HSD test was used to test for statistical differences. Means \pm standard deviations are shown.

Different letters indicate differences among the cultivars for each gene separately at $\mathrm{p}<0.05$ of probability

\subsection{ABA Sensitivity of Seedlings}

Exogenous application of ABA at low concentrations retarded root elongation to a different degree. Cultivar GK Élet showed significantly the weakest response to 10 and $20 \mu \mathrm{M}$ ABA applications (Figure 5).

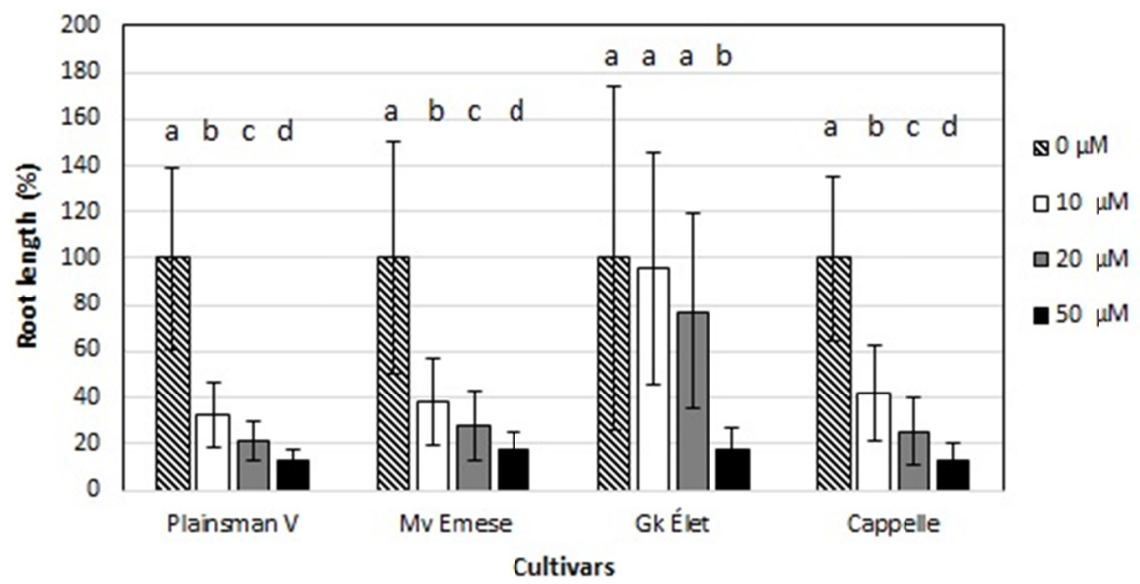

Figure 5. Relative root lengths of seedlings after one week growth at the indicated ABA concentrations $(10,20$ and $50 \mu \mathrm{M})$ were compared to untreated controls. Welch's ANOVA test $\left(\mathrm{F}^{(3,125,9)}=158,5 ; \mathrm{p}=0,000\right)$ was used to test for statistically significant differences among data sets of genotypes and hormone concentrations. Means \pm standard deviations are shown. Different letters indicate differences at $\mathrm{p}<0.05$ of probability

\section{Discussion}

Drought tolerance is a complex phenotype with multi factorial determination (Ashraf, 2010). Studies presented here focused on expression of potentially stress related genes as well as ABA sensitivity in wheat genotypes with 
contrasting ability to tolerate water stress. The investigated attributes may indicate differences in stress response mechanisms with potential contribution to drought hardiness.

This work is an extension of earlier experiments (Jäger et al., 2014) where several traits potentially contributing to different drought tolerance level of four selected bread wheat cultivars have already been identified. Smaller leaf area and lower stomatal number pro leaves were found in the tolerant varieties, while a thin and water permeable cuticle was described in the sensitive cv. Cappelle Desprez. Besides morphological traits, stress induced morpho-physiological changes also differentiated the cultivars especially after repeated exposures to water deficit. Loss of cellular integrity (indicated by increased electrolyte leakage), more severe ultrastructural damage to the chloroplasts and faster decline of relative water content of leaves were characteristic to the sensitive cultivars during repeated drought cycles (Jäger et al., 2014). Apparently the two tolerant genotypes exhibited stronger defencesagainst oxidative damage at the cellular level. This coincided with higher glutathione synthase and glutathione peroxidase activity in cv. Plainsman V as was established by Gallé and co-workers (2009). Therefore, several facets of the more effective drought tolerance response of Plainsman V and Mv Emese have been already uncovered. Different responses to water shortage were confirmed in our present experiments, as tolerant cultivars exhibited significantly higher relative water content values in leaves already at the end of one water deprivation period applied (Figure 2).

Given the high complexity of the drought tolerant phenotype we hypothesized that further relevant physiological differences could still be established among these cultivars. In a search for further clues explaining differences, expression levels of potential stress tolerance related genes were studied.

Dehydrin genes are well appreciated targets of $C b f$ genes when responding to cold. Parallel expression of $D H N$ and $C b f$ genes has been found in cold stress (e.g. Kume et al., 2005). Cbf and other cold responsive genes were found activated by ABA independent and ABA dependent pathways as well (Knight et al., 2004). More recently Cbf gene expression has been also linked to induction of a dehydrin gene during the drought tolerance response of Brachypodium distachyon (Ryu et al., 2014). Wdhn13 is probably subject to regulation by multiple transcription factors, including $C b f$ genes. The $W c b f 2$ wheat transcription factor has been shown to activate the promoter of $W d h n 13$ in tobacco (Takumi et al., 2008). Transcriptional regulation of $W d h n 13$ involving $C b f$ genes under drought conditions fits well with our data. In this study dehydrin and $C b f$ gene specific RT-PCR reactions were performed on leaf samples from drought stressed plants of the four genotypes around anthesis. Data indicated that Wdhn13, Cbf14 and Cbf15 genes showed coordinate induction in Mv Emese during a late stage of the water limitation period. This induction of dehydrin and $C B F$ genes occurred at approximately one week after total water deprivation and was most pronounced in Mv Emese, a genotype with high tolerance and yield under drought stress conditions. Based on this expression pattern in drought stressed adult plants Wdhn13 (and probably other dehydrins) may be regulated by both $C b f$ genes. In order to confirm association between drought, stress-induced $C B F /$ dehydrin gene expression at anthesis and drought tolerance, a larger number of genotypes ought to be examined. Transcript profiles of Wdreb2 and other potential regulators as well as more dehydrin genes should be tested in this respect.

We presumed that a clearer picture could be obtained about interactions among dehydrin and $C b f$ genes by examining plants exposed to as low a level of stress as possible. To this end the same set of genes was investigated in leaves of non-stressed young seedlings. According to observations of Rorat and co-workers (2004) in five Solanaceae species and barley, leaves of young, developing seedlings exhibited high dehydrin protein levels even in the absence of stress. Similarly, light induced expression of a dehydrin-encoding gene, HaDhnl, was found in sunflower seedlings in the absence of environmental stresses (Natali et al., 2007). This made us speculate that wheat seedlings may also express at least some $D H N$ and/or $C b f$ genes spontaneously (i.e. probably as a result of the unavoidable, very low level of stress received during cultivation). In order to minimize stress factors as much as possible, wheat seedlings were well watered and a constant temperature was applied to exclude cold induced gene expression. Target gene expression was investigated by quantitative qRT-PCR. Cultivar specific expression of the genes was found, which didn't match with that found around anthesis (day 0 of drought treatment). This confirms that transcription of $C b f$ and dehydrin genes may be subject to development specific regulation. In seedlings of some cultivars $C b f 14$ and $C b f 15$ transcripts were found expressed at moderate and at very low levels, respectively. This contrasted with parallel expression of $C b f 14$ and Cbf15 in adult stage plants under drought stress implying that the two genes may be regulated by different mechanisms. Independent regulation of the two genes was also shown earlier by Knox et al. (2008) in cold stress.

The dehydrin gene $W d h n 13$ was found highly expressed in unstressed seedlings of the two tolerant varieties but at a lower level in the sensitive cultivars. A potential connection between dehydrin expression early in plant 
development and drought tolerance of adult plants should be further investigated on a larger set of genes and cultivars. It is worth noting however that high levels of a desiccation induced dehydrin protein at the seedling stage werealso correlated with adult stage drought tolerance in wheat (Lopez et al., 2001).

ABA sensitivity of root growth has been associated with drought tolerance in wheat (Kurahashi et al., 2009). As ABA is also known to activate expression of some dehydrin genes, we performed an in vitro experiment to this end. In our study ABA induced root growth retardation of GK Élet was found to be consistently weaker at low external hormone concentrations (10 and $20 \mu \mathrm{M}$ ABA applied) in comparison with the other three cultivars. This data suggest that ABA insensitivity may contribute to the low level of drought tolerance of GK Élet, and confirm that $\mathrm{ABA}$ responsiveness may be a factor of drought sensitivity in some wheat cultivars. No direct correlation was found however between inducibility of the genes studied and ABA sensitivity of the cultivars. Stress induced modification of root growth in cvs Mv Emese and GK Élet has been also characterized by Tari et al. (2010). Smaller osmotically (PEG) induced reduction of root growth rate was found in GK Élet, which corresponds well with our findings. In the experiment of Tari et al. (2010) endogenous ABA content of the root tips remained unchanged in GK Élet, but decreased in Mv Emese. Our data about ABA insensitivity can explain why the relatively higher ABA content could still not have led to efficient growth retardation in Gk Élet root tips. ABA responsiveness of root elongation can be measured at the seedling stage, making this method especially feasible for early pre-screening drought sensitivity of breeding lines.

We conclude that pronounced and coordinate induction of $C b f$ and dehydrin genes (Cbf14, Cbf15 and Wdhn13) in a late stage of water stress in a tolerant genotype (Mv Emese) at anthesis may represent a module in the multi facet phenotype of drought hardiness. We propose that the other tolerant cultivar involved in our studies (Plainsman V) probably uses alternative strategies to avoid detrimental effects of drought. Morphological traits may support lower level of water loss in this cultivar (Jäger et al., 2014). Evading water shortage by accelerated development of the root system may also be a part of an acclimation process in Plainsman V. This aspect of the water stress response however, was not investigated in our studies. A further basic factor of drought tolerance is ABA responsiveness, which is apparently weak in the cultivar Gk Élet, probably contributing to its sensitivity. Our experiments also uncovered expression of the Wdhn 13 dehydrin gene in leaves of unstressed seedlings in the tolerant cultivars. Whether this implies differences in sensitivity of signalling steps leading to defencegene expression needs further investigations.

\section{Acknowledgements}

The work was supported by the TÁMOP 4.2.1/B-09/1/KMR/-2010-0005, NKTH-OTKA CK80211, NKTH-OTKA CK80274 and NKTH K108644 grants from the National Development Agency of Hungary. The authors would like to thank Dr Gábor Galiba for providing primers for Cbf genes, Dr László Gáspár and Dr András Ittzés for help in data management and statistics, Erika Gondos and András Miskó for excellent technical assistance and David J Cleary for language editing. Csilla Deák and Réka Oszlányi were partially supported by the Doctoral School of Horticultural Science of Szent István University.

\section{References}

Ashraf, M. (2010). Inducing drought tolerance in plants: Recent advances. Biotechnology Advances, 28(1), 169-183. https://doi.org/10.1016/j.biotechadv.2009.11.005

Battaglia, M., Olvera-Carrill, O. Y., Garciarrubio, A., Campos, F., \& Covarrubias, A. A. (2008). The enigmatic LEA proteins and other hydrophilins. Plant Physiol., 148(1), 6-24. https://doi.org/10.1104/pp.108.120725

Cutler, S., Ghassemian, M., Bonetta, D., Cooney, S., \& McCourt, P. (1996). A protein farnesyl transferase involved in abscisic acid signal transduction in Arabidopsis. Science, 273(5279), 1239-41. https://doi.org/ $10.1126 /$ science.273.5279.1239

Dunnett, C. W. (1955). A multiple comparison procedure for comparing several treatments with a control. Journal of the American Statistical Association, 50, 1096-1121. https://doi.org/10.1080/01621459.1955. 10501294

Galiba, G., Vágúffalvi, A., Li., C., Soltész, A., \& Dubcovsky, J. (2009). Regulatory genes involved in the determination of frost tolerance in temperate cereals. Plant Science, 176, 12-19. https://doi.org/10.1016/ j.plantsci.2008.09.016

Gallé, A., Csiszár, J., Secenji, M., Guóth, A., Cseuz, L., Tari, I., Györgyey, J., \& Erdei, L. (2009). Glutathione transferase activity and expression patterns during grain filling in flag leaves of wheat genotypes differing in drought tolerance: Response to water deficit. J. Plant Physiol., 166(17), 1878-91. https://doi.org/10.1016/ j.jplph.2009.05.016 
Golldack, D., Li, C., Mohan, H., \& Probst, N. (2014). Tolerance to drought and salt stress in plants: Unraveling the signaling networks. Front Plant Sci., 5, 151. https://doi.org/10.3389/fpls.2014.00151

Guóth, A., Tari, I., Gallé, Á., Csiszár, J., Pécsváradi, A., Cseuz, L., \& Erdei, L. (2009). Comparison of the drought stress responses of tolerant and sensitive wheat cultivars during grain filling: Changes in flag leaf photosynthetic activity, ABA levels, and grain yield. J. Plant Growth Regul., 28, 167-176. https://doi.org/10.1007/s00344-009-9085-8

Hara, M. (2010). The multifunctionality of dehydrins, An overview. Plant Signaling \& Behavior, 5(5), $503-508$. https://doi.org/10.4161/psb.11085

Hegedűs, A., Erdei, S., Janda, T., Tóth, E., Horváth, G., \& Dudits, D. (2004). Transgenic tobacco plants overproducing alfalfa aldose/aldehyde reductase show higher tolerance to low temperature and cadmium stress. Plant Science, 166(5), 1329-1333. https://doi.org/10.1016/j.plantsci.2004.01.013

Hugouvieux, V., Kwak, J. M., \& Schroeder, J. I. (2001). An mRNA cap binding protein, ABH1, modulates early abscisic acid signal transduction in Arabidopsis. Cell., 106(4), 477-87. https://doi.org/10.1016/S0092-8674 (01)00460-3

Jäger, K., Fábián, A., Eitel, G., Szabó, L., Deák, C., Barnabás, B., \& Papp, I. (2014). A morpho-physiological approach differentiates bread wheat cultivars of contrasting tolerance under cyclic water stress. J. Plant Physiol., 171, 1256-1266. https://doi.org/10.1016/j.jplph.2014.04.013

Kidokoro, S., Watanabe, K., Ohori, T., Moriwaki, T., Maruyama, K., Mizoi, J., ... Yamaguchi-Shinozaki, K. (2015). Soybean DREB1/CBF-type transcription factors function in heat and drought as well as cold stress-responsive gene expression. Plant J., 81(3), 505-18. https://doi.org/10.1111/tpj.12746

Knight, H., Zarka, D. G., Okamoto, H., Thomashow, M. F., \& Knight, M. R. (2004). Abscisic acid induces CBF gene transcription and subsequent induction of cold-regulated genes via the CRT promoter element. Plant Physiol., 135(3), 1710-7. https://doi.org/10.1104/pp.104.043562

Knox, A. K., Li, C., Vágújfalvi, A., Galiba, G., Stockinger, E. J., \& Dubcovsky, J. (2008). Identification of candidate $\mathrm{CBF}$ genes for the frost tolerance locus Fr-Am2 in Triticum monococcum. Plant Mol. Biol., 67(3), 257-70. https://doi.org/10.1007/s11103-008-9316-6

Kume, S., Kobayashi, F., Ishibashi, M., Ohno, R., Nakamura, C., \& Takumi, S. (2005). Differential and coordinated expression of $\mathrm{Cbf}$ and Cor/Lea genes during long-term cold acclimation in two wheat cultivars showing distinct levels of freezing tolerance. Genes Genet Syst., 80(3), 185-97. https://doi.org/10.1266/ ggs.80.185

Kurahashi, Y., Terashima, A., \& Takumi, S. (2009). Variation in dehydration tolerance, ABA sensitivity and related gene expression patterns in D-genome progenitor and synthetic hexaploid wheat lines. Int. J. Mol. Sci., 10, 2733-2751. https://doi.org/10.3390/ijms10062733

Lee, S. C., \& Luan, S. (2012). ABA signal transduction at the crossroad of biotic and abiotic stress responses. Plant Cell Environ., 35(1), 53-60. https://doi.org/10.1111/j.1365-3040.2011.02426.x

Lopez, C. G., Banowetz, G., Peterson, C. J., \& Kronstad, W. E. (2001). Differential accumulation of a 24-kd dehydrin protein in wheat seedlings correlates with drought stress tolerance at grain filling. Hereditas., 135(2-3), 175-81. https://doi.org/10.1111/j.1601-5223.2001.00175.x

McCurdy, R. D., McGrath, J. J., \& MacKay-Sim, A. (2008). Validation of the comparative quantification method of real-time PCR analysis and a cautionary tale of housekeeping gene selection. Gene Therapy and Molecular Biology., 12(1), 15-24.

Miller, A. K., Galiba, G., \& Dubcovsky, J. (2006). A cluster of 11 CBF transcription factors is located at the frost tolerance locus Fr-Am2 in Triticum monococcum. Mol. Genet. Genomics., 275(2), 193-203. https://doi.org/ 10.1007/s00438-005-0076-6

Mizoi, J., Shinozaki, K., \& Yamaguchi-Shinozaki, K. (2012). AP2/ERF family transcription factors in plant abiotic stress responses. Biochim Biophys Acta., 1819(2), 86-96. https://doi.org/10.1016/j.bbagrm.2011. 08.004

Natali, L., Giordani, T., Lercari, B., Maestrini, P., Cozza, R., Pangaro, T., ... Cavallini, A. (2007). Light induces expression of a dehydrin-encoding gene during seedling de-etiolation in sunflower (Helianthus annuus L.). J. Plant Physiol., 164(3), 263-73. https://doi.org/10.1016/j.jplph.2006.01.015 
Ohno, R., Takumi, S., \& Nakamura, C. (2003). Kinetics of transcript and protein accumulation of a low-molecular-weight wheat LEA D-11 dehydrin in response to low temperature. J. Plant Physiol., 160(2), 193-200. https://doi.org/10.1078/0176-1617-00925

Paolacci, A. R., Tanzarella, O. A., Porceddu, E., \& Ciaffi, M. (2009). Identification and validation of reference genes for quantitative RT-PCR normalization in wheat. BMC Mol. Biol., 10, 11. https://doi.org/10.1186/ 1471-2199-10-11

Papp, I., Mur, L. A., Dalmadi, A., Dulai, S., \& Koncz, C. (2004). A mutation in the Cap Binding Protein 20 gene confers drought tolerance to Arabidopsis. Plant Mol. Biol., 55(5), 679-86. https://doi.org/10.1007/s11103004-1680-2

Rampino, P., Pataleo, S., Gerardi, C., Mita, G., \& Perrotta, C. (2006). Drought stress response in wheat: Physiological and molecular analysis of resistant and sensitive genotypes. Plant Cell Environ., 29(12), 2143-52. https://doi.org/10.1111/j.1365-3040.2006.01588.x

Rorat, T., Grygorowicz, W. J., Irzykowski, W., \& Rey, P. (2004). Expression of KS-type dehydrins is primarily regulated by factors related to organ type and leaf developmental stage during vegetative growth. Planta, 218(5), 878-85. https://doi.org/10.1007/s00425-003-1171-8

Ryu, J. Y., Hong, S. Y., Jo, S. H., Woo, J. C., Lee, S., \& Park, C. M. (2014). Molecular and functional characterization of cold-responsive C-repeat binding factors from Brachypodium distachyon. BMC Plant Biol., 14, 15. https://doi.org/10.1186/1471-2229-14-15

Soltész, A., Smedley, M., Vashegyi, I., Galiba, G., Harwood, W., \& Vágújfalvi, A. (2013). Transgenic barley lines prove the involvement of TaCBF14 and TaCBF15 in the cold acclimation process and in frost tolerance. J. Exp. Bot., 64(7), 1849-62. https://doi.org/10.1093/jxb/ert050

Takumi, S., Shimamura, C., \& Kobayashi, F. (2008). Increased freezing tolerance through up-regulation of downstream genes via the wheat CBF gene in transgenic tobacco. Plant Physiol. Biochem., 46(2), $205-11$. https://doi.org/10.1016/j.plaphy.2007.10.019

Tari, I., Guóth, A., Benyó, D., Kovács, J., Poór, P., \& Wodala, B. (2010). The roles of ABA, reactive oxygen species and nitric oxide in root growth during osmotic stress in wheat: comparison of a tolerant and a sensitive variety. Acta Biol. Hung., 61, 189-96. https://doi.org/10.1556/ABiol.61.2010.Suppl.18

Thole, J. M., Beisner, E. R., Liu, J., Venkova, S. V., \& Strader, L. C. (2014). Abscisic Acid Regulates Root Elongation through the Activities of Auxin and Ethylene in Arabidopsis thaliana. G3 (Bethesda). May 15. pii: g3.114.011080.

Tischner, T., Kőszegi, B., \& Veisz, O. (1997). Climatic programmes used in the Martonvásár phytotron most frequently in recent years. Acta Agron Hung., 45, 85-104.

Wang, Y., Xu, H., Zhu, H., Tao, Y., Zhang, G., Zhang, L., ... Ma, Z. (2014). Classification and expression diversification of wheat dehydrin genes. Plant Sci., 214, 113-20. https://doi.org/10.1016/j.plantsci. 2013.10.005

Xiao, H., Siddiqua, M., Braybrook, S., \& Nassuth, A. (2006). Three grape CBF/DREB1 genes respond to low temperature, drought and abscisic acid. Plant Cell Environ., 29(7), 1410-21. https://doi.org/10.1111/ j.1365-3040.2006.01524.x

Zadoks, I. C., Chang, T. T., \& Konzak, C. F. (1974). A decimal code for the growth stages of cereals. Weed Res., 14, 415-421. https://doi.org/10.1111/j.1365-3180.1974.tb01084.x

\section{Copyrights}

Copyright for this article is retained by the author(s), with first publication rights granted to the journal.

This is an open-access article distributed under the terms and conditions of the Creative Commons Attribution license (http://creativecommons.org/licenses/by/4.0/). 